STUDIA PRAWNO-EKONOMICZNE, t. CIV, 2017

PL ISSN 0081-6841; e-ISSN 2450-8179 $\quad$ s. 329-343

DOI: 10.26485/SPE/2017/104/19

\title{
KAPITAL LUDZKI JAKO FILAR GOSPODARKI OPARTEJ NA WIEDZY - ANALIZA STANU REGIONALNEGO ZRÓŻNICOWANIA W POLSCE
}

\begin{abstract}
(Streszczenie)
Celem badań była ocena regionalnego zróżnicowania poziomu kapitału ludzkiego w Polsce oraz zmian, jakie zaszły w tym zakresie w latach 1999-2014. Wyniki przeprowadzonych analiz podsumować można następująco. Regionalne zróżnicowanie poziomu kapitału ludzkiego w Polsce wzrosło, nadal utrzymuje się jednak na poziomie umiarkowanym. Przyczyną rosnących regionalnych dysproporcji w tym zakresie są równolegle zachodzące procesy konwergencji i dywergencji wewnętrznej województw, w tym również o charakterze marginalizacji. Liderami pod względem poziomu kapitału ludzkiego są województwa mazowieckie i małopolskie, które dystansują pozostałe obszary kraju. Najniższym poziomem kapitału ludzkiego charakteryzuje się województwo lubuskie, którego dystans w stosunku do pozostałych województw pogłębia się, co świadczyć może o niebezpiecznym zjawisku marginalizacji tego regionu.
\end{abstract}

Słowa kluczowe: kapitał ludzki; gospodarka oparta na wiedzy; regionalne zróżnicowanie; dywergencja; konwergencja

Klasyfikacja JEL: I21, I25, R11

\section{Wstęp}

Współczesną gospodarkę określa się mianem gospodarki opartej na wiedzy lub nawet napędzanej wiedzą. Strategicznymi czynnikami jej rozwoju gospodarczego stała się bowiem wiedza, zdolność do jej tworzenia, absorpcji oraz wykorzystania.

* Dr, Uniwersytet Warmińsko-Mazurski w Olsztynie, Wydział Nauk Ekonomicznych, Katedra Makroekonomii; e-mail: wioletta.wierzbicka@uwm.edu.pl 
Rozwój gospodarki opartej na wiedzy wymaga wzajemnych powiązań jej podstawowych elementów (filarów wiedzy), czyli kapitału ludzkiego, technologii informacyjnych i komunikacyjnych oraz systemów innowacyjności. Spójny rozwój tych dziedzin wpływa bowiem na produktywność i wzrost gospodarczy, które w znaczący sposób determinują jeszcze otoczenie instytucjonalne ${ }^{1}$. Za najważniejszy „,nośnik” wiedzy uznaje się przy tym kapitał ludzki², bez którego nie jest możliwe odkrywanie oraz optymalne wykorzystanie innych zasobów ${ }^{3}$. Kapitał ludzki jest pojęciem złożonym i niejednoznacznym. Jest on ucieleśniony w człowieku i jest z nim nierozerwalnie związany ${ }^{4}$. W wąskim ujęciu rozumiany jest on jako poziom wykształcenia społeczeństwa w danej gospodarce ${ }^{5}$, jako kapitał edukacji w sensie ilościowym ${ }^{6}$. W szerokim ujęciu, utożsamia się go z zasobami wiedzy, umiejętnościami, kompetencjami, poziomem zdrowia, a nawet energii witalnej społeczeństwa ${ }^{7}$. Inaczej ujmując, do kapitału ludzkiego zalicza się nie tylko ilościowe ujęcie edukacji formalnej, ale również jej jakość, strukturę, wszelkie umiejętności i kompetencje ludzi zdobywane poza systemem szkolnictwa, jak również zdrowie ${ }^{8}$. Bez względu na sposób definiowania kapitału ludzkiego, jego rola w gospodarce opartej na wiedzy sukcesywnie wzrasta. Kapitał ludzki jest bowiem „nośnikiem” wiedzy i innowacji, które decydują

1 R. Przybyszewski, Kapitat ludzki w procesie ksztattowania gospodarki opartej na wiedzy, Difin, Warszawa 2007, s. 74.

2 S. Korenik, Region ekonomiczny w nowych realiach społeczno-gospodarczych, CeDeWu, Warszawa 2011, s. 42.

3 A. Organiściak-Krzykowska, Wykształcenie jako element jakości zasobów pracy, w: A. Rączaszek, W. Koczur (red.), Polityka spoteczna w procesie integracji europejskiej. Przeglad problematyki, Prace Naukowe Akademii Ekonomicznej im. Karola Adamieckiego, Katowice 2009, s. 376.

4 D. Makulska, Kluczowe czynniki rozwoju w gospodarce opartej na wiedzy, Prace i Materiały Instytutu Rozwoju Gospodarczego SGH 2012/88, s. 182.

5 W. Florczak, Kapitat ludzki w empirycznych modelach wzrostu, Ekonomista 2008/2, s. 171; M. Niklewicz-Pijaczyńska, M. Wachowska, Wiedza-Kapital ludzki-Innowacje, Prawnicza i Ekonomiczna Biblioteka Cyfrowa, Wrocław 2012, s. 45.

6 E. Soszyńska, Budowa gospodarki wiedzy a dynamika rozwoju gospodarczego i realna konwergencja gospodarcza, Referat na IX Kongres Ekonomistów Polskich, Warszawa 2013, http:// www.pte.pl/kongres/referaty/?dir=Soszynska+E; stan na 20.01.2017 r.

7 S. Marciniak (red.), Perspektywy kapitału ludzkiego jako czynnika wzrostu gospodarczego Polski, Politechnika Warszawska, Kolegium Nauk Społecznych i Administracji, Warszawa 2002, s. 7; R. Przybyszewski, op. cit., s. 49; A.A. Peters, Building Human Capital for Sustainable Development: Role of the University, University of Ibadan 2013, http://ui.edu.ng/sites/default/ files/UI\%20PAPER.pdf; stan na 18.01.2017 r.

8 E. Soszyńska, op. cit. 
o zdolności gospodarek krajowych, regionalnych i lokalnych do skutecznego konkurowania i rozwoju?

Podstawowym sposobem nabywania kapitałowości ludzkiej jest edukacja. Stanowi ona najprostszy sposób, by zwiększyć jakość posiadanego kapitału ludzkiego, zarówno w wymiarze ogólnonarodowym, jak i indywidualnym. W dobie gospodarki opartej na wiedzy niezmiernie ważna staje się więc poprawa jakości edukacji i rozwój kształcenia ustawicznego ${ }^{10}$. Dobrze wykształcone i wykwalifikowane społeczeństwo jest niezbędne do efektywnego tworzenia, nabywania, rozpowszechniania i wykorzystywania wiedzy, która przyczynia się do zwiększenia całkowitej produktywności czynników produkcji i tym samym wzrostu gospodarczego ${ }^{11}$. Wykształcona i wykwalifikowana kadra jest nową jakością w szeroko rozumianym kapitale ludzkim i nie tyko przesądza o większym potencjale gospodarczym kraju, ale stanowi podwaliny pod zupełnie inny kierunek ewolucji społecznej ${ }^{12}$. Wysokiej jakości kapitał ludzki przyspiesza bowiem procesy tworzenia oraz dyfuzji wiedzy i innowacji, to z kolei generuje proces kształtowania się gospodarki opartej na wiedzy oraz wpływa na kierunek rozwoju społeczno-gospodarczego kraju bądź regionu.

W świetle powyższego, celem badań stała się ocena regionalnego zróżnicowania poziomu kapitału ludzkiego w Polsce oraz zmian, jakie zaszły w tym zakresie w latach 1999-2014. Podjęto próbę udzielenia odpowiedzi na pytanie: Jaka jest skala regionalnego zróżnicowania poziomu kapitału ludzkiego w Polsce i czy zachodzi w tym zakresie proces dywergencji, czy też konwergencji regionalnej? Udzielenie odpowiedzi na tak postawione pytanie badawcze jest istotne, chociażby z uwagi na fakt, iż rosnące dysproporcje w poziomie kapitału ludzkiego w poszczególnych województwach mogą przekładać się na pogłębianie regionalnych dysproporcji w poziomie rozwoju gospodarczego.

Badania przeprowadzono na poziomie regionalnym NUTS II. W badaniach wykorzystano metodę porządkowania liniowego opartą na zmiennej syntetycznej oraz metodę grupowania obiektów uporządkowanych liniowo.

9 R. Przybyszewski, op. cit., s. 49.

${ }_{10}$ K. Piech, Gospodarka oparta na wiedzy i jej rozwój w Polsce, E-mentor 2004/4 (6), s. 37.

11 D.H.C. Chen, C.J. Dahlman, The Knowledge Economy, the KAM Methodology and World Bank Operations, World Bank and OECD, Washington 2006, s. 9.

12 M. Klonowska-Matynia, A. Lisowska, Rola systemu ksztatcenia kapitału ludzkiego wobec potrzeb rynku pracy $w$ procesie realizacji zatożeń gospodarki opartej na wiedzy $w$ Polsce, w: G. Maniak (red.), Problemy ekonomii i polityki gospodarczej, Wydawnictwo Katedry Mikroekonomii Uniwersytetu Szczecińskiego, Szczecin 2008, s. 90. 


\section{Pomiar kapitału ludzkiego w ujęciu regionalnym}

Pomiar kapitału ludzkiego nie jest zadaniem prostym. Komplikacje w jego pomiarze wynikają zarówno z samej definicji, bowiem jest to pojęcie heterogeniczne, jak również z faktu, iż większość składników kapitału ludzkiego jest niemierzalna. Do oceny poziomu kapitału ludzkiego wykorzystuje się więc najczęściej wskaźniki syntetyczne, które wyznaczane są na podstawie zestawu zmiennych będących przybliżeniem dla tego rodzaju kapitału. W literaturze przedmiotu wyróżnia się m.in.: podejście oparte na parametrach edukacji (statystyki dotyczące poziomu alfabetyzacji, skolaryzacji, przeciętnego czasu nauki i tym podobne) oraz metody oparte na indeksach, które są konstruowane na podstawie miar edukacyjnych, demograficznych i innych danych szczegółowych z rynku pracy ${ }^{13}$.

Autorzy, dokonując doboru zmiennych, starają się wybierać takie, które w jak najlepszy sposób opisują badane zjawisko, są adekwatne do przyjętej definicji i poziomu prowadzonej analizy, kierują się ponadto dostępnością danych dla przyjętego okresu badawczego. W literaturze przedmiotu znaleźć można tym samym wiele opracowań, w których badania dotyczące kapitału ludzkiego, w tym również jako jednego z filarów gospodarki opartej na wiedzy, prowadzone są na podstawie zestawu różnych zmiennych ${ }^{14}$.

W niniejszych badaniach kapitał ludzki rozumiany jest jako poziom wykształcenia społeczeństwa w danej gospodarce. Do zmiennych stanowiących przybliżenie do tak rozumianego kapitału ludzkiego zalicza się m.in.: odsetek populacji z umiejętnościami czytania i pisania, współczynnik skolaryzacji brutto i netto, relacje między liczbą nauczycieli i uczniów, udział nakładów na edukację

13 I. Miciuła, K. Miciuła, Metody pomiaru wartości kapitału ludzkiego, Zeszyty Naukowe Uniwersytetu Szczecińskiego nr 858, Współczesne Problemy Ekonomiczne 2015/11, s. 273.

14 Patrz: Z. Chojnicki, T. Czyż, Polska na ścieżce rozwoju gospodarki opartej na wiedzy. Podejście regionalne, Przegląd Geograficzny 2003/75/1; A. Kukliński, W. Burzyński, The Development of Knowledge-Based Economy in Europe: the Regional Trajectory - Model 4+4+4+22, w: K. Piech (red.), The Knowledge-Based Economy in Transition Countries: Selected Issues, University College London - School of Slavonic and East European Studies, London 2004; W. Florczak, Pomiar gospodarki opartej na wiedzy w badaniach międzynarodowych, Wiadomości Statystyczne 2010/2; M. Niklewicz-Pijaczyńska, M. Wachowska, op. cit.; E. Dworak, T. Grabia, W. Kasperkiewicz, W. Kwiatkowska, Gospodarka oparta na wiedzy, innowacyjność i rynek pracy, Wydawnictwo Uniwersytetu Łódzkiego, Łódź 2014; P. Merło, M. Bogdański, J. Michalak, Kapitał ludzki a rynek pracy $w$ województwie warmińsko-mazurskim, w: P. Merło, J. Michalak (red.), Efekty inwestowania w ksztatcenie kadry menadżerskiej dla potrzeb regionalnego rynku pracy, Wydział Nauk Ekonomicznych UWM w Olsztynie, Olsztyn 2015. 
w PKB, liczbę studentów i słuchaczy studiów podyplomowych w przeliczeniu na liczbę ludności czy też odsetek studentów kierunków technicznych.

Biorąc powyższe pod uwagę, autorka dokonała doboru zmiennych pod względem merytorycznym ${ }^{15}$, formalnym ${ }^{16}$ oraz statystycznym i ostatecznie w zbiorze zmiennych diagnostycznych, na podstawie których zbudowano syntetyczny wskaźnik kapitału ludzkiego, znalazły się następujące zmienne:

$X_{1}$ - współczynnik skolaryzacji netto uczniów zasadniczych szkół zawodowych w \% ludności w wieku 16-18 $\left(w_{1}=0,16\right)$,

$X_{2}$ - współczynnik skolaryzacji netto uczniów liceów ogólnokształcących W \% ludności w wieku 16-18 $\left(w_{2}=0,20\right)$,

$X_{3}$ - liczba studentów szkół wyższych przypadających na 1000 ludności $\left(w_{3}=0,30\right)$,

$X_{4}-$ liczba słuchaczy studiów podyplomowych na 1000 ludności $\left(w_{4}=0,08\right)$,

$X_{5}$ - liczba uczących się obowiązkowo języka angielskiego w szkołach dla dzieci i młodzieży oraz policealnych w przeliczeniu na 1000 ludności $\left(w_{5}=0,11\right)$, $X_{6}$ - wydatki publiczne na oświatę i wychowanie wyrażone w \% PKB $\left(w_{6}=0,15\right)$.

Syntetyzację zmiennych przeprowadzono przy wykorzystaniu metod bezwzorcowych, które polegają na operacji uśrednienia wartości unormowanych zmiennych ${ }^{17}$. Normalizację zmiennych przeprowadzono przy wykorzystaniu procedury unitaryzacji zerowanej, przy czym z uwagi na fakt, iż wszystkim zmiennym diagnostycznym przypisano charakter stymulant ${ }^{18}$, procedurę unitaryzacji przeprowadzono według następującej formuły ${ }^{19}$ :

15 Zgodnie z koncepcją gospodarki opartej na wiedzy, w której kapitał ludzki jest jednym z jej filarów, niektóre zmienne, które również mogłyby być utożsamiane z kapitałem ludzkim nie są uwzględniane w tym filarze, lecz w filarze opisującym system innowacji. W badaniach autorki również zastosowano takie podejście. Artykuł jest bowiem jednym z cyklu artykułów dotyczących problematyki regionalnego zróżnicowania GOW w Polsce. Patrz: W. Wierzbicka, The Innovation System as a Pillar for a Knowledge-Based Economy - an Analysis of Regional Diversity in Poland, Olsztyn Economic Journal 2016/11 (4).

16 Sporym ograniczeniem w doborze zmiennych była dostępność kompletnych danych statystycznych na poziomie NUTS 2 dla tak długiego szeregu czasowego.

17 K. Kukuła, L. Luty, Propozycja procedury wspomagającej wybór metody porządkowania liniowego, Przegląd Statystyczny 2015/2, s. 219.

18 Charakter zmiennych diagnostycznych określono na podstawie przesłanek merytorycznych. Weryfikację przyjętego charakteru zmiennych przeprowadzono ex post, sprawdzając skorelowanie poszczególnych zmiennych ze zmienną syntetyczną.

19 T. Panek, J. Zwierzchowski, Statystyczne metody wielowymiarowej analizy porównawczej. Teoria i zastosowania, Oficyna Wydawnicza Szkoły Głównej Handlowej w Warszawie, Warszawa 2013, s. 37. 


$$
z_{i j}=\frac{x_{i j}-\min _{i}\left\{x_{i j}\right\}}{\max _{i}\left\{x_{i j}\right\}-\min _{i}\left\{x_{i j}\right\}} \quad i=1,2, \ldots, n ; \quad j=1,2, \ldots, m,
$$

gdzie:

$z_{i j}$ - znormalizowana wartość $j$-tej zmiennej diagnostycznej w $i$-tym obiekcie, $x_{i j}$ - wartość $j$-tej zmiennej diagnostycznej w $i$-tym obiekcie,

$\min _{i}\left\{x_{i j}\right\}, \max _{i}\left\{x_{i j}\right\}$ - wartość min i max j-tej zmiennej diagnostycznej w zbiorze obiektów.

W celu zapewnienia porównywalności województw w danym roku, jak również pomiędzy latami, zmienne diagnostyczne potraktowano jako dane panelowe. $Z$ technicznego punktu widzenia oznaczało to, że w formule, według której przeprowadzano unitaryzację, wartość minimalną i maksymalną każdej zmiennej wyznaczono z całego panelu danych obejmujących wszystkie lata i województwa. Unormowane w ten sposób zmienne diagnostyczne poddano procedurze syntetyzacji, zgodnie z następującą formułą agregującą ${ }^{20}$ :

$$
s_{i}=\frac{1}{m} \sum_{j=1}^{m} z_{i j} w_{j} \quad i=1,2, \ldots, n ; \quad j=1,2, \ldots, m,
$$

gdzie:

$s_{i}$ - wartość zmiennej syntetycznej w $i$-tym obiekcie,

$z_{i j}$ - wartość znormalizowanej j-tej zmiennej diagnostycznej w $i$-tym obiekcie,

$w_{j}$ - waga przypisana $j$-tej zmiennej diagnostycznej ${ }^{21}$,

$m$ - liczba zmiennych diagnostycznych.

Syntetyczny wskaźnik kapitału ludzkiego przyjął wartości z przedziału [0, 1]. Wyższa wartość wskaźnika oznacza korzystniejszą sytuację województwa pod względem badanych cech.

\section{Regionalne zróżnicowanie poziomu kapitału ludzkiego w Polsce}

Skalę regionalnego zróżnicowania poziomu kapitału ludzkiego w Polsce oceniono na podstawie wartości syntetycznego wskaźnika kapitału ludzkiego w województwach w latach 1999-2014, które przedstawiono w tabeli 1. Wartości wyższe od średniej dla Polski w danym roku odpowiednio wyróżniono.

Ibidem, s. 63.

21 Wagi przypisane poszczególnym zmiennym nadane zostały przez ekspertów, którzy wzięli udział w badaniu przeprowadzonym przez autorkę przy wykorzystaniu metody delfickiej. 
TABELA 1: Syntetyczny wskaźnik kapitału ludzkiego w województwach w latach 1999-2014

\begin{tabular}{|c|c|c|c|c|c|c|c|c|c|c|c|c|c|c|c|c|c|}
\hline \multirow[b]{2}{*}{ Województwo } & \multicolumn{16}{|c|}{ Wartość syntetycznego wskaźnika kapitału ludzkiego w latach } & \multirow{2}{*}{$\begin{array}{c}\text { Dynami- } \\
\text { ka zmian } \\
1999- \\
2014\end{array}$} \\
\hline & $\stackrel{2}{2}$ & ஓ̊̊ & ఠ্ণ & ฮิ & లి & ষ্ণ & $\stackrel{\overbrace{}}{8}$ & ஓ̊ & 용 & $\stackrel{\infty}{8}$ & 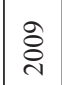 & $\stackrel{\circ}{\stackrel{2}{\circ}}$ & ప & 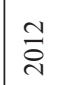 & $\stackrel{m}{\circ}$ & $\stackrel{ \pm}{\text { ป }}$ & \\
\hline Dolnośląskie & 0,34 & 0,42 & 0,46 & 0,44 & 0,46 & 0,51 & 0,51 & 0,50 & 0,52 & 0,54 & 0,55 & 0,52 & 0,50 & 0,48 & 0,45 & 0,44 & 1,29 \\
\hline $\begin{array}{l}\text { Kujawsko- } \\
\text {-Pomorskie }\end{array}$ & 0,36 & 0,42 & 0,47 & 0,42 & 0,43 & 0,48 & 0,47 & 0,46 & 0,47 & 0,48 & 0,49 & 0,48 & 0,47 & 0,45 & 0,43 & 0,42 & 1,17 \\
\hline Lubelskie & 0,45 & 0,53 & 0,56 & 0,53 & 0,55 & 0,61 & 0,61 & 0,60 & 0,62 & 0,62 & 0,65 & 0,64 & 0,62 & 0,60 & 0,55 & 0,53 & 1,18 \\
\hline Lubuskie & 0,26 & 0,34 & 0,36 & 0,32 & 0,33 & 0,37 & 0,37 & 0,33 & 0,33 & 0,32 & 0,33 & 0,32 & 0,30 & 0,28 & 0,26 & 0,26 & 1,00 \\
\hline Łódzkie & 0,32 & 0,40 & 0,45 & 0,43 & 0,43 & 0,49 & 0,49 & 0,50 & 0,53 & 0,55 & 0,55 & 0,51 & 0,49 & 0,47 & 0,44 & 0,42 & 1,31 \\
\hline Małopolskie & 0,42 & 0,49 & 0,56 & 0,52 & 0,54 & 0,60 & 0,61 & 0,62 & 0,65 & 0,68 & 0,69 & 0,69 & 0,67 & 0,65 & 0,60 & 0,58 & 1,38 \\
\hline Mazowieckie & 0,48 & 0,58 & 0,63 & 0,61 & 0,60 & 0,64 & 0,65 & 0,64 & 0,67 & 0,67 & 0,67 & 0,64 & 0,63 & 0,63 & 0,61 & 0,59 & 1,23 \\
\hline Opolskie & 0,27 & 0,35 & 0,39 & 0,33 & 0,34 & 0,39 & 0,39 & 0,39 & 0,42 & 0,44 & 0,46 & 0,47 & 0,45 & 0,41 & 0,38 & 0,35 & 1,30 \\
\hline Podkarpackie & 0,32 & 0,42 & 0,46 & 0,44 & 0,47 & 0,51 & 0,51 & 0,48 & 0,50 & 0,52 & 0,53 & 0,53 & 0,52 & 0,49 & 0,46 & 0,44 & 1,38 \\
\hline Podlaskie & 0,40 & 0,49 & 0,53 & 0,47 & 0,47 & 0,51 & 0,51 & 0,50 & 0,52 & 0,53 & 0,55 & 0,55 & 0,54 & 0,52 & 0,48 & 0,45 & 1,13 \\
\hline Pomorskie & 0,35 & 0,41 & 0,46 & 0,40 & 0,43 & 0,47 & 0,46 & 0,47 & 0,49 & 0,53 & 0,54 & 0,54 & 0,52 & 0,53 & 0,51 & 0,50 & 1,43 \\
\hline Śląskie & 0,30 & 0,37 & 0,40 & 0,38 & 0,38 & 0,42 & 0,42 & 0,42 & 0,42 & 0,43 & 0,43 & 0,43 & 0,41 & 0,39 & 0,36 & 0,35 & 1,17 \\
\hline $\begin{array}{l}\text { Świętokrzy- } \\
\text { skie }\end{array}$ & 0,36 & 0,47 & 0,51 & 0,46 & 0,45 & 0,51 & 0,50 & 0,49 & 0,48 & 0,48 & 0,50 & 0,50 & 0,47 & 0,45 & 0,41 & 0,39 & 1,08 \\
\hline $\begin{array}{l}\text { Warmińsko- } \\
\text {-Mazurskie }\end{array}$ & 0,34 & 0,43 & 0,48 & 0,43 & 0,44 & 0,49 & 0,49 & 0,47 & 0,49 & 0,49 & 0,50 & 0,48 & 0,46 & 0,44 & 0,40 & 0,38 & 1,12 \\
\hline Wielkopolskie & 0,32 & 0,39 & 0,45 & 0,41 & 0,42 & 0,46 & 0,48 & 0,48 & 0,51 & 0,53 & 0,52 & 0,53 & 0,52 & 0,50 & 0,48 & 0,47 & 1,47 \\
\hline $\begin{array}{l}\text { Zachodniopo- } \\
\text { morskie }\end{array}$ & 0,47 & 0,51 & 0,53 & 0,48 & 0,47 & 0,50 & 0,48 & 0,47 & 0,47 & 0,48 & 0,48 & 0,46 & 0,45 & 0,41 & 0,38 & 0,36 & 0,77 \\
\hline $\begin{array}{l}\text { Średnia dla } \\
\text { Polski }\end{array}$ & 0,36 & 0,44 & 0,48 & 0,45 & 0,46 & 0,50 & 0,51 & 0,50 & 0,52 & 0,53 & 0,54 & 0,53 & 0,51 & 0,49 & 0,46 & 0,45 & \\
\hline $\begin{array}{l}\text { Odch. stand. } \\
\text { dla populacji }\end{array}$ & 0,06 & 0,07 & 0,07 & 0,07 & 0,07 & 0,07 & 0,07 & 0,08 & 0,08 & 0,09 & 0,09 & 0,09 & 0,09 & 0,09 & 0,09 & 0,09 & \\
\hline $\begin{array}{l}\text { Współczynnik } \\
\text { zmienności }\end{array}$ & 16,7 & 15,9 & 14,6 & 15,6 & 15,2 & 14,0 & 13,7 & 16,0 & 15,4 & 17,0 & 16,7 & 17,0 & 17,6 & 18,4 & 19,6 & 20,0 & \\
\hline
\end{tabular}

Źr ó dło: obliczenia własne na podstawie danych pochodzących z Roczników Statystycznych poszczególnych województw z lat 2000-2015.

Porównując wartości syntetycznego wskaźnika kapitału ludzkiego z roku 1999 i 2014, stwierdzić należy, iż poziom kapitału ludzkiego w większości polskich województw wyraźnie się poprawił. Rok 2014 nie był jednak rokiem, w którym województwa charakteryzowały się najwyższym jego poziomem. Większość województw najwyższy poziom syntetycznego wskaźnika kapitału ludzkiego odnotowała w roku 2009 i w kolejnych latach notowała jego spadek. Pomimo to w roku 2014 aż 14 województw cechowało się wyższym poziomem kapitału 
ludzkiego niż na początku badanego okresu. Jedno województwo - lubuskie - cechowało się takim samym poziomem kapitału ludzkiego jak w roku 1999 i tylko w jednym z województw - zachodniopomorskim - poziom kapitału ludzkiego uległ obniżeniu. Najwyższe tempo wzrostu syntetycznego wskaźnika kapitału ludzkiego odnotowały województwa wielkopolskie (47\%) i pomorskie (43\%). Najniższe tempo wzrostu odnotowały natomiast województwa świętokrzyskie $(8 \%)$, warmińsko-mazurskie $(12 \%)$ i podlaskie $(13 \%)$.

Co istotne, w całym badanym okresie regionalne zróżnicowanie poziomu kapitału ludzkiego w Polsce kształtowało się na poziomie umiarkowanym. Skala tego zróżnicowania wykazywała jednak tendencję rosnącą. Potwierdzeniem tego jest wartość współczynnika zmienności, który z poziomu 16,7\% w roku 1999 , wzrósł do poziomu $20 \% \mathrm{w}$ roku 2014. Wzrost regionalnych dysproporcji w poziomie kapitału ludzkiego w Polsce jest jeszcze bardziej widoczny, gdy pod uwage weźmiemy rok 2005, w którym współczynnik zmienności osiagnął najniższą wartość wynoszącą 13,7\%. Na uwagę zasługuje przy tym fakt, iż regionalnej dywergencji poziomu kapitału ludzkiego w Polsce towarzyszyły równolegle zachodzące procesy konwergencji i dywergencji wewnętrznej województw. Identyfikację charakteru procesów wewnętrznych zachodzących w poszczególnych województwach przeprowadzono na podstawie odpowiedniej klasyfikacji, której podstawą był poziom syntetycznego wskaźnika kapitału ludzkiego w 1999 r. i jego dynamika zmian w latach 1999-2014 w stosunku do średniej dla ogółu województw. Wyniki grupowania przedstawiono w tabeli 2.

Procesy o charakterze konwergencji zidentyfikowano w odniesieniu do 9 województw. W przypadku 6 z nich miały one charakter efektu doganiania, w przypadku pozostałych 3 - efektu spowalniania. Konwergencja o charakterze doganiania cechowała województwa: dolnośląskie, łódzkie, opolskie, podkarpackie, pomorskie i wielkopolskie. W 1999 r. województwa te odnotowały znacznie niższy od średniej dla ogółu województw poziom syntetycznego wskaźnika kapitału ludzkiego, jednak z uwagi na znacznie wyższą od średniej dynamikę wzrostu w tym zakresie, ich sytuacja w porównaniu do przeciętnej sytuacji w województwach poprawiła się. Konwergencja drugiego typu wystąpiła z kolei w województwach: lubelskim, podlaskim i zachodniopomorskim. Spowolnienie, spowodowane niższą od średniej dla ogółu województw dynamiką zmian zachodzących w zakresie poziomu ich kapitału ludzkiego, nie wpłynęło wprawdzie na sytuację województwa lubelskiego, które utrzymało wysoką lokatę wśród województw, spowodowało jednak pogorszenie sytuacji województwa zachodniopomorskiego i podlaskiego. 
TABELA 2: Klasyfikacja województw ze względu na charakter procesów wewnętrznych zachodzacych w zakresie kapitału ludzkiego w latach 1999-2014

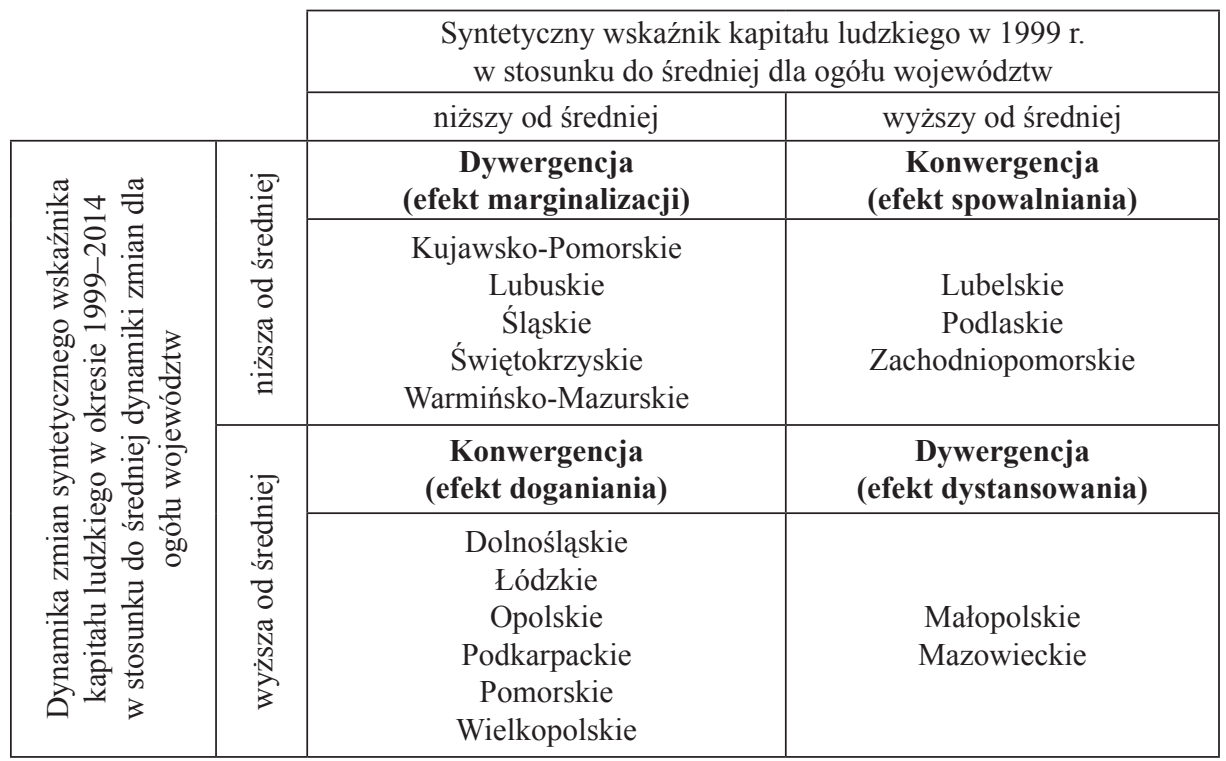

Ź r ó dło: opracowanie własne na podstawie danych zawartych w tabeli 1.

Procesy dywergencji zachodzące w pozostałych 7 województwach również miały dwojaki charakter. Województwa małopolskie i mazowieckie cechowały się wysokim poziomem kapitału ludzkiego na początku badanego okresu oraz wyższą od średniej dynamiką wzrostu w tym zakresie, a tym samym dystansowały pozostałe obszary kraju. W pozostałych pięciu województwach procesy dywergencji miały charakter efektu marginalizacji, bowiem dystans między nimi a pozostałymi województwami pogłębiał się. Najgorszą sytuację pod tym względem odnotowano w województwie lubuskim. W 1999 r. syntetyczny wskaźnik kapitału ludzkiego w tym województwie był niższy od średniej dla ogółu województw o 27,8\%, natomiast w 2014 r. już o 39,5\%.

W konsekwencji zachodzących procesów, pozycja poszczególnych województw względem pozostałych uległa dosyć istotnym zmianom, czego potwierdzeniem są wyniki rankingów województw sporządzone dla poszczególnych lat (tabela 3). 
TABELA 3: Ranking województw wedlug syntetycznego wskaźnika kapitału ludzkiego w latach 1999-2014

\begin{tabular}{|c|c|c|c|c|c|c|c|c|c|c|c|c|c|c|c|c|c|}
\hline \multirow[b]{2}{*}{ Województwo } & \multicolumn{16}{|c|}{ Pozycja w rankingu w latach } & \multirow{2}{*}{$\begin{array}{c}\text { Zmiana } \\
\text { pozycji } \\
\text { w latach } \\
\text { 1999-2014 }\end{array}$} \\
\hline & ฉે & 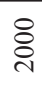 & ఠి & §ิ & §ิ & ণั & 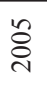 & ๕્̀ & $\hat{\varnothing}$ & $\stackrel{\infty}{8}$ & ठ્ণ & $\stackrel{\circ}{\circ}$ & $\overrightarrow{\vec{\sim}}$ & $\stackrel{\sim}{\stackrel{\sim}{N}}$ & $\stackrel{m}{i}$ & $\stackrel{\nabla}{\stackrel{\sim}{~}}$ & \\
\hline Dolnośląskie & 9 & 9 & 10 & 8 & 7 & 5 & 4 & 6 & 5 & 5 & 6 & 8 & 8 & 8 & 8 & 8 & +1 \\
\hline $\begin{array}{l}\text { Kujawsko- } \\
\text {-Pomorskie }\end{array}$ & 7 & 8 & 8 & 11 & 11 & 11 & 12 & 13 & 12 & 13 & 12 & 12 & 11 & 10 & 10 & 10 & -3 \\
\hline Lubelskie & 3 & 2 & 2 & 2 & 2 & 2 & 3 & 3 & 3 & 3 & 3 & 3 & 3 & 3 & 3 & 3 & 0 \\
\hline Lubuskie & 16 & 16 & 16 & 16 & 16 & 16 & 16 & 16 & 16 & 16 & 16 & 16 & 16 & 16 & 16 & 16 & 0 \\
\hline Łódzkie & 13 & 12 & 12 & 10 & 10 & 9 & 8 & 4 & 4 & 4 & 4 & 9 & 9 & 9 & 9 & 9 & +4 \\
\hline Małopolskie & 4 & 4 & 3 & 3 & 3 & 3 & 2 & 2 & 2 & 1 & 1 & 1 & 1 & 1 & 2 & 2 & +2 \\
\hline Mazowieckie & 1 & 1 & 1 & 1 & 1 & 1 & 1 & 1 & 1 & 2 & 2 & 2 & 2 & 2 & 1 & 1 & 0 \\
\hline Opolskie & 15 & 15 & 15 & 15 & 15 & 15 & 15 & 15 & 15 & 14 & 14 & 13 & 14 & 13 & 14 & 14 & +1 \\
\hline Podkarpackie & 12 & 10 & 9 & 7 & 4 & 4 & 5 & 8 & 8 & 9 & 8 & 6 & 7 & 7 & 7 & 7 & +5 \\
\hline Podlaskie & 5 & 5 & 4 & 5 & 5 & 7 & 6 & 5 & 6 & 6 & 5 & 4 & 4 & 5 & 6 & 6 & -1 \\
\hline Pomorskie & 8 & 11 & 11 & 13 & 12 & 12 & 13 & 10 & 10 & 8 & 7 & 5 & 5 & 4 & 4 & 4 & +4 \\
\hline Śląskie & 14 & 14 & 14 & 14 & 14 & 14 & 14 & 14 & 14 & 15 & 15 & 15 & 15 & 15 & 15 & 15 & -1 \\
\hline $\begin{array}{l}\text { Świętokrzy- } \\
\text { skie }\end{array}$ & 6 & 6 & 6 & 6 & 8 & 6 & 7 & 7 & 11 & 11 & 11 & 10 & 10 & 11 & 11 & 11 & -5 \\
\hline $\begin{array}{l}\text { Warmińsko- } \\
\text {-Mazurskie }\end{array}$ & 10 & 7 & 7 & 9 & 9 & 10 & 9 & 12 & 9 & 10 & 10 & 11 & 12 & 12 & 12 & 12 & -2 \\
\hline Wielkopolskie & 11 & 13 & 13 & 12 & 13 & 13 & 11 & 9 & 7 & 7 & 9 & 7 & 6 & 6 & 5 & 5 & +6 \\
\hline $\begin{array}{l}\text { Zachodniopo- } \\
\text { morskie }\end{array}$ & 2 & 3 & 5 & 4 & 6 & 8 & 10 & 11 & 13 & 12 & 13 & 14 & 13 & 14 & 13 & 13 & -11 \\
\hline
\end{tabular}

Źr ódło: opracowanie własne na podstawie danych przedstawionych w tabeli 1 .

Ranking ma dwóch zdecydowanych liderów: województwo mazowieckie i małopolskie. Atutem województwa mazowieckiego jest najwyższa w kraju liczba słuchaczy studiów podyplomowych w przeliczeniu na liczbę mieszkańców, najwyższy w kraju współczynnik skolaryzacji netto uczniów liceów ogólnokształcących oraz duża liczba studentów szkół wyższych w przeliczeniu na liczbę mieszkańców. Atutem województwa małopolskiego jest natomiast najwyższa w kraju liczba studentów szkół wyższych w przeliczeniu na liczbę mieszkańców, jeden z najwyższych w kraju współczynnik skolaryzacji netto uczniów zasadniczych szkół zawodowych oraz duża liczba uczących się obowiązkowo języka angielskiego w przeliczeniu na liczbę ludności.

Najgorzej w rankingu wypada województwo lubuskie, które w całym badanym okresie zajmuje ostatnią pozycję na liście rankingowej. Słabą stroną tego województwa jest najniższa w kraju liczba studentów szkół wyższych, liczba 
słuchaczy studiów podyplomowych i uczących się obowiązkowo języka angielskiego w przeliczeniu na liczbę mieszkańców oraz współczynnik skolaryzacji netto uczniów liceów ogólnokształcących. Słabą pozycję w rankingach w całym badanym okresie zajmują również województwa opolskie i śląskie, a w ostatnich latach również zachodniopomorskie. Co istotne, sytuacja województwa zachodniopomorskiego pogorszyła się w badanym okresie na tyle, że z 2 lokaty w roku 1999 przesunęło się ono aż na 13 pozycję w roku 2014. Poziom syntetycznego wskaźnika kapitału ludzkiego w województwie zachodniopomorskim zmalał w tym okresie aż o $23 \%$, a wpłynęły na to następujące czynniki: najwyższy w kraju spadek liczby studentów szkół wyższych w przeliczeniu na liczbę ludności (aż 45\%), najniższa w kraju dynamika wzrostu współczynnika skolaryzacji netto uczniów liceów ogólnokształcących (tylko 1,2) oraz niskie tempo wzrostu liczby uczących się obowiązkowo języka angielskiego w przeliczeniu na liczbę ludności (tylko 17\% wobec 74\% w województwie wielkopolskim, które odnotowało najwyższe tempo wzrostu w kraju).

Warto przy tym nadmienić, iż wysokie tempo wzrostu liczby uczących się obowiązkowo języka angielskiego, jak również relatywnie wysoki wzrost liczby studentów szkół wyższych oraz słuchaczy studiów podyplomowych w województwie wielkopolskim spowodowały, iż województwo to odnotowało w badanym okresie najbardziej znaczącą poprawę na liście rankingowej województw. Z 11 lokaty w roku 1999 przesunęło się ono na 5 lokatę w roku 2014 i sklasyfikowane zostało do grupy województw o wysokim poziomie kapitału ludzkiego (rysunek 1).

RYSUNEK 1: Wyniki grupowania województw wedtug poziomu kapitału ludzkiego w roku 2014

Bardzo wysoki poziom kapitału ludzkiego Wysoki poziom kapitału ludzkiego Niski poziom kapitału ludzkiego Bardzo niski poziom kapitału ludzkiego

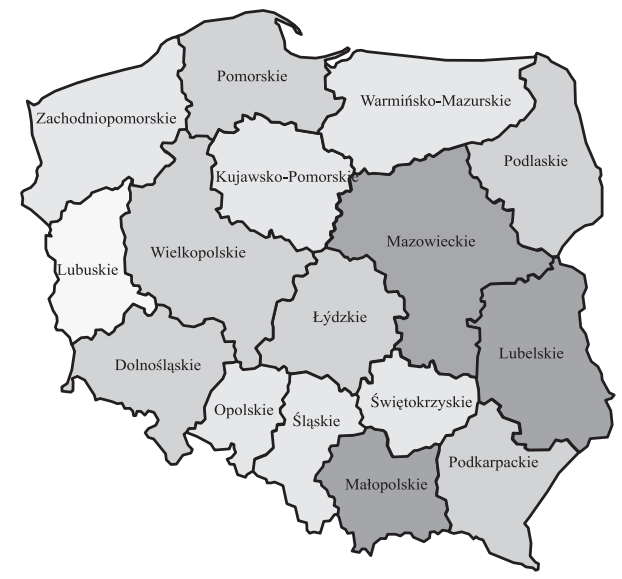

Źr ód ło: opracowanie własne na podstawie danych przedstawionych w tabeli 1. 
Klasyfikację województw przeprowadzono za pomocą metody odchyleń standardowych ${ }^{22}$. Granice przedziałów wyznaczono na podstawie wartości średniej arytmetycznej syntetycznego wskaźnika kapitału ludzkiego dla ogółu województw $(\bar{s})$ oraz poziomu odchylenia standardowego tego wskaźnika $S(s)$, w badanym roku. Zbiór badanych obiektów podzielono na cztery grupy typologiczne:

1. Grupa o bardzo wysokim poziomie kapitału ludzkiego, obejmująca obiekty o wartościach syntetycznego wskaźnika należących do przedziału $s_{i} \geq+S(s)$ a więc $s_{i} \geq 0,52$;

2. Grupa o wysokim poziomie kapitału ludzkiego, obejmująca obiekty o wartościach syntetycznego wskaźnika należących do przedziału $\bar{s}+S(s)>s_{i} \geq \bar{s}$, a więc $s_{i} \geq 0,43$;

3. Grupa o niskim poziomie kapitału ludzkiego, obejmująca obiekty o wartościach syntetycznego wskaźnika należących do przedziału $\overline{\mathrm{s}}>s_{i} \geq \overline{\mathrm{s}}-S(s)$, a więc $0,43>s_{i} \geq 0,34$;

4. Grupa o bardzo niskim poziomie kapitału ludzkiego, obejmująca obiekty o wartościach syntetycznego wskaźnika należących do przedziału $s_{i}<\overline{\mathrm{s}}-S(s)$, a więc $s_{i}<0,34$;

Obok wspomnianego wcześniej województwa wielkopolskiego, w grupie województw o wysokim poziomie kapitału ludzkiego znalazło się jeszcze 5 województw, w tym dwa województwa Polski Wschodniej - podlaskie i podkarpackie. Trzy województwa - mazowieckie, małopolskie i lubelskie sklasyfikowane zostały do grupy województw o bardzo wysokim poziomie kapitału ludzkiego, a tylko jedno z województw - lubuskie sklasyfikowane zostało do grupy województw o bardzo niskim poziomie kapitału ludzkiego.

\section{Zakończenie}

W latach 1999-2014 poziom kapitału ludzkiego w większości województw uległ znaczącej poprawie. Dynamika zmian zachodzących w tym zakresie w poszczególnych województwach była jednak bardzo zróżnicowana. Najwyższe tempo wzrostu syntetycznego wskaźnika kapitału ludzkiego odnotowano w województwie wielkopolskim (47\%) i pomorskim (43\%). Najniższe tempo wzrostu, bo

22 M. Kunasz, Przykład zastosowania metod WAP do analizy procesów gospodarowania zasobami ludzkimi w przedsiębiorstwie, w: D. Kopycińska (red.), Kapitat ludzki w gospodarce opartej na wiedzy, Wydawnictwo Printgroup, Szczecin 2006, s. 131-139. 
jedynie $8 \%$, odnotowano natomiast w województwie świętokrzyskim. Tylko w jednym z województw - zachodniopomorskim - odnotowano spadek poziomu kapitału ludzkiego (niestety aż o 23\%). W jednym z województw - lubuskim - poziom kapitału ludzkiego na początku i na końcu badanego okresu ukształtował się na takim samym poziomie.

W konsekwencji tak zróżnicowanej dynamiki zmian oraz znacznego zróżnicowania poziomu kapitału ludzkiego na początku badanego okresu w zbiorowości województw obserwowano równolegle zachodzące procesy konwergencji i dywergencji wewnętrznej, w tym również o charakterze marginalizacji. Procesy o charakterze konwergencji zachodziły w badanym okresie w 9 województwach. W przypadku 6 z nich: dolnośląskiego, tódzkiego, opolskiego, podkarpackiego, pomorskiego i wielkopolskiego miały one charakter efektu doganiania, w przypadku 3: lubelskiego, podlaskiego i zachodniopomorskiego - charakter efektu spowalniania. W pozostałych 7 województwach zachodziły w tym okresie procesy dywergencji wewnętrznej. Co istotne, w przypadku aż 5 z nich: kujawsko-pomorskiego, lubuskiego, śląskiego, świętokrzyskiego i warmińsko-mazurskiego procesy te miały charakter efektu marginalizacji. Oznacza to, że sytuacja tych województw w porównaniu do przeciętnej sytuacji w województwach pogorszyła się, a tym samym zwiększył się dystans dzielący te województwa od pozostałych.

W wyniku równolegle zachodzących procesów konwergencji i dywergencji wewnętrznej województw regionalne zróżnicowanie poziomu kapitału ludzkiego w Polsce wzrosło, nadal utrzymuje się jednak na umiarkowanym poziomie. Potwierdzeniem tego jest m.in. wartość współczynnika zmienności, która z poziomu 16,7\% w 1999 r. wzrosła do poziomu 20\% w 2014 r., jak również wzrost relacji maksymalnej i minimalnej wartości syntetycznego wskaźnika kapitału ludzkiego w danym roku. W roku 1999 wynosiła ona 1,8, natomiast w roku 2014 przyjęła wartość 2,3.

Reasumując i próbując udzielić odpowiedzi na postawione pytanie badawcze, stwierdzić można, iż regionalne zróżnicowanie poziomu kapitału ludzkiego w Polsce pogłębia się, nadal utrzymuje się jednak na poziomie umiarkowanym. Zachodzące procesy dywergencji uznać należy za tendencję niekorzystną, gdyż rosnące regionalne dysproporcje w poziomie kapitału ludzkiego w Polsce mogą przekładać się na pogłębianie się regionalnych różnic w poziomie rozwoju gospodarczego kraju. 


\section{Bibliografia}

\section{Opracowania}

Chen Derek H.C., Dahlman Carl J., The Knowledge Economy, the KAM Methodology and World Bank Operations, World Bank and OECD, Washington 2006.

Chojnicki Zbyszko, Czyż Teresa, Polska na ścieżce rozwoju gospodarki opartej na wiedzy. Podejście regionalne, Przegląd Geograficzny 2003/75/1, s. 23-39.

Dworak Edyta, Grabia Tomasz, Kasperkiewicz Witold, Kwiatkowska Walentyna, Gospodarka oparta na wiedzy, innowacyjność i rynek pracy, Wydawnictwo Uniwersytetu Łódzkiego, Łódź 2014.

Florczak Waldemar, Pomiar gospodarki opartej na wiedzy $w$ badaniach międzynarodowych, Wiadomości Statystyczne 2010/2, s. 78-97.

Florczak Waldemar, Kapitat ludzki w empirycznych modelach wzrostu, Ekonomista 2008/2, s. $169-200$.

Klonowska-Matynia Maria, Lisowska Agnieszka, Rola systemu kształcenia kapitału ludzkiego wobec potrzeb rynku pracy w procesie realizacji zatożeń gospodarki opartej na wiedzy w Polsce, w: Grażyna Maniak (red.), Problemy ekonomii i polityki gospodarczej, Wydawnictwo Katedry Mikroekonomii Uniwersytetu Szczecińskiego, Szczecin 2008.

Korenik Stanisław, Region ekonomiczny w nowych realiach społeczno-gospodarczych, $\mathrm{CeDeWu}$, Warszawa 2011.

Kukliński Antoni, Burzyński Wojciech, The Development of Knowledge-Based Economy in Europe: the Regional Trajectory - model 4+4+4+22, w: Krzysztof Piech (red.), The Knowledge-Based Economy In Transition Countries: Selected Issues, University College London - School of Slavonic and East European Studies, London 2004.

Kukuła Karol, Luty Lidia, Propozycja procedury wspomagajacej wybór metody porządkowania liniowego, Przegląd Statystyczny 2015/2, s. 219-231.

Kunasz Marek, Przyktad zastosowania metod WAP do analizy procesów gospodarowania zasobami ludzkimi w przedsiębiorstwie, w: Danuta Kopycińska (red.), Kapitał ludzki w gospodarce opartej na wiedzy, Wydawnictwo Printgroup, Szczecin 2006.

Makulska Danuta, Kluczowe czynniki rozwoju w gospodarce opartej na wiedzy, Prace i Materiały Instytutu Rozwoju Gospodarczego SGH 2012/88, s. 169-193.

Marciniak Stefan (red.), Perspektywy kapitalu ludzkiego jako czynnika wzrostu gospodarczego Polski, Politechnika Warszawska, Kolegium Nauk Społecznych i Administracji, Warszawa 2002.

Merło Pawel, Bogdański Marcin, Michalak Jacek, Kapitał ludzki a rynek pracy w województwie warmińsko-mazurskim, w: Paweł Merło, Jacek Michalak (red.), Efekty inwestowania w kształcenie kadry menadżerskiej dla potrzeb regionalnego rynku pracy, Wydział Nauk Ekonomicznych UWM w Olsztynie, Olsztyn 2015.

Miciuła Ireneusz, Miciuła Krzysztof, Metody pomiaru wartości kapitału ludzkiego, Zeszyty Naukowe Uniwersytetu Szczecińskiego nr 858, Współczesne Problemy Ekonomiczne 2015/11, s. $269-280$.

Niklewicz-Pijaczyńska Małgorzata, Wachowska Malgorzata, Wiedza-Kapitat ludzki-Innowacje, Prawnicza i Ekonomiczna Biblioteka Cyfrowa, Wrocław 2012.

Organiściak-Krzykowska Anna, Wyksztatcenie jako element jakości zasobów prac, w: Andrzej Rączaszek, Wiesław Koczur (red.), Polityka społeczna w procesie integracji europejskiej. 
Przegląd problematyki, Prace Naukowe Akademii Ekonomicznej im. Karola Adamieckiego, Katowice 2009.

Panek Tomasz, Zwierzchowski Jan, Statystyczne metody wielowymiarowej analizy porównawczej. Teoria i zastosowania, Oficyna Wydawnicza Szkoły Głównej Handlowej w Warszawie, Warszawa 2013.

Peters Ajibade A., Building Human Capital for Sustainable Development: Role of the University, University of Ibadan 2013, http://ui.edu.ng/sites/default/files/UI\%20PAPER.pdf; stan na 18.01.2017 r.

Piech Krzysztof, Gospodarka oparta na wiedzy i jej rozwój w Polsce, E-mentor 2004/4 (6), s. $36-42$.

Przybyszewski Roman, Kapitał ludzki w procesie ksztattowania gospodarki opartej na wiedzy, Difin, Warszawa 2007.

Soszyńska Elżbieta, Budowa gospodarki wiedzy a dynamika rozwoju gospodarczego i realna konwergencja gospodarcza, Referat na IX Kongres Ekonomistów Polskich, Warszawa 2013, http://www.pte.pl/kongres/referaty/?dir=Soszynska+E; stan na 20.01.2017 r.

Wierzbicka Wioletta, The Innovation System as a Pillar for a Knowledge-Based Economy - an Analysis of Regional Diversity in Poland, Olsztyn Economic Journal 2016/11 (4), s. 343-357.

Wioletta WIERZBICKA

\section{HUMAN CAPITAL AS A PILLAR OF KNOWLEDGE-BASED ECONOMY - AN ANALYSIS OF THE REGIONAL DIVERSITY IN POLAND}

( Su m mary)

The aim of our study has been to assess the regional diversity in the level of the human capital in Poland and the changes that occurred in this regard over the period of 1999-2014. The results of our analyses can be summarised as follows. Regional differences in the level of human capital in Poland have grown but are still moderate. The causes of the increasing regional disproportions are the ongoing parallel convergence and divergence processes within the provinces, including ones which correspond to marginalisation. The leaders in terms of the human capital were the Province of Masovia (województwo mazowieckie) and Province of Malopolska (województwo małopolskie), which outdistance all other Polish provinces. The lowest level of human capital was determined in Lubuskie Province (województwo lubuskie), which is increasingly staying behind the rest of Poland, a fact that may indicate dangerous marginalisation of this region.

Keywords: human capital; knowledge-based economy; reginal diversity; divergence; convergence 